\title{
Managing sandstorms through resettling pastoralists in China: how multiple forms of power govern the environment at/across scales
}

\author{
Qian Zhang ${ }^{1}$ \\ Stockholm University, Sweden
}

\begin{abstract}
This study uses concepts of power and 'scaled politics' to analyze the effects of environmentalization and technocratic and market-based measures in China. Political scientists have explored the politics behind the proactive engagement of the Chinese state in governing the environment since the 2000s, also drawing on political ecology. Based on policy document analysis and ethnographic fieldwork, the study investigates a case of ecological resettlement in Inner Mongolia by examining how this became a new solution to desertification and rangeland degradation. The article shows how resettlement was implemented through multi-scalar practices and the reconfiguration of spatial relations, and why pastoral households responded to resettlement in certain ways. The state turned certain areas and people (associated with overgrazing) into subjects of governance. By distinguishing the different strategies used by central and local government, the analysis shows that disciplinary and neoliberal environmentality are associated with scalar practices between the state and the people, and within the state system. Neoliberal environmentality, however, counteracts the making of environmental subjects and encounters resistance. Sovereign environmentality is still deployed as a means to control local government and the obedience of herders. Pastoralists resist this, depending on their different subjectivities. The study advances our understanding of the multiple governmentality perspective, its analytics, and scalar processes.
\end{abstract}

Keywords: Power; scale; China; environmental state; pastoralists; environmentality; degradation; desertification; resettlement

\section{Résumé}

Les politologues ont exploré la politique derrière l'engagement proactif de l'Etat chinois dans la gouvernance de l'environnement depuis les années 2000. Cette étude utilise des concepts de pouvoir et de "politique à l'échelle» pour analyser les effets de l'environnementalisation et des mesures technocratiques et fondées sur le marché en Chine. Basée sur l'analyse des documents de politique et le travail de terrain ethnographique, l'étude étudie un cas de réinstallation écologique en Mongolie-Intérieure en examinant comment la réinstallation est devenue une nouvelle solution à la désertification et à la dégradation des parcours. L'article montre comment il a été mis en œuvre à travers des pratiques multi-scalaires et la reconfiguration des relations spatiales, et pourquoi les ménages pastoraux ont réagi à la réinstallation de certaines manières. L'État a transformé certaines zones et personnes (associées au surpâturage) en sujets de gouvernance. En distinguant les différentes stratégies utilisées par le gouvernement central et local, l'analyse montre que l'environnementalité disciplinaire et néolibérale est associée à des pratiques scalaires entre l'État et le peuple, et au sein du système étatique. L'environnementalité néolibérale, cependant, neutralise la fabrication de sujets environnementaux et rencontre une résistance.

Dr. Qian Zhang, Researcher, Department of Human Geography, Stockholm University, Sweden. Email: qian.zhang "at" humangeo.su.se. I would like to thank the Norwegian national research network on Political Ecology and Environmental Policy for inviting me to the workshop 'Power in Political Ecology' in Bergen in November 2015, where the drafting of this article started. Thanks to the anonymous peer reviewer, Hanne Svarstad and Ragnhild Overå for giving very helpful comments on the earlier drafts, without which this article would not have evolved into its current form. The article was developed in part from my doctoral research, and I also acknowledge the pastoralists interviewed who generously shared their experiences and knowledge with me. Financial support for doctoral research was kindly offered by Axel the Lagrelius fond för geografisk forskning, the Carl Mannerfelts fond, Knut och Alice Wallenbergs Stiftelse, and the Forum for Asian Studies at Stockholm University; and Bo Malmberg, Andrew Byerley, Xiaoyi Wang and Jenny Cadstedt who supervised the growth of my ideas. This is the first article in Hanne Svarstad, Tor A. Benjaminsen and Ragnhild Overå (eds.). 2018. "Power in political ecology", Special Section of the Journal of Political Ecology 25: 350-425. 
L'environnementalité souveraine est encore déployée comme un moyen de contrôler le gouvernement local et l'obéissance des éleveurs. Les éleveurs y résistent, en fonction de leurs différentes subjectivités. L'étude fait progresser notre compréhension de la perspective de la gouvernementalité multiple, de ses analyses et de ses processus scalaires.

Mots-clés: Puissance; échelle; Chine; l'état environnemental; les éleveurs; l'environnementalité; dégradation; la désertification; réinstallation.

\section{Resumen}

El ámbito político detrás del compromiso proactivo del Estado Chino en el gobierno del medioambiente desde los 2000s y efectos posteriores, ha sido explorado principalmente por la ciencia política que nunca ha utilizado conceptos similares a los de ecología política (EP), tales como poder y escala. Este estudio se basa en ideas sobre diferentes formas de poder y el campo político a escala dentro de la ecología política, para analizar los actuales procesos y efectos de la ambientalización en China, para así, profundizar en nuestro entendimiento de la política crucial detrás del acercamiento neoliberal respaldado por medidas tecnocráticas y basadas en el mercado. Con base en el análisis de documentos normativos y trabajo etnográfico, el estudio investiga particularmente un caso de reasentamiento ecológico en Mongolia interior. Esto, con una mirada hacia cómo el reasentamiento se vuelve una nueva solución para la desertificación y la degradación de los pastizales, cómo se implementa a través de prácticas multi escala, así como hacia la reconfiguración de las relaciones espaciales, y por qué los hogares de pastores respondieron de ciertas maneras a este reasentamiento. Los hallazgos sugieren que la visibilidad de las tormentas de arena fue tomada en cuenta con efectividad por parte del Estado para convertir ciertas áreas (el área fuente) y cierta población (asociada con pastoreo excesivo) en sujetos de gobernanza. Haciendo distinción de las diferentes estrategias entre los gobiernos central y local, el análisis identifica que el ambientalismo disciplinario y neoliberal, está asociado con diferentes prácticas escalares entre el estado y la gente, así como dentro del sistema de estado. El ambientalismo neoliberal sin embargo, contrarresta la formación de sujetos ambientales, mismo caso de la resistencia del ambientalismo de verdad. El ambientalismo soberano es aún implementado como un medio efectivo para forzar al gobierno local y a los pastores a la obediencia. La resistencia varía entre los hogares de pastores con base en sus diferentes subjetividades, más frecuentemente resistiendo a la formación de agentes modernos, que a la formación de agentes ambientales. El estudio anticipa nuestro entendimiento de una perspectiva de gubernamentalidad múltiple, su analítica y sus procesos escalares.

Palabras clave: poder, escala, Estado ambiental, pastores, ambientalismo, China, degradación, desertificación, reasentamiento

\section{Introduction}

Political ecology scholarship occupies a small share of the rapidly growing literature on environmental governance in China (Yeh 2015). Political scientists have explored the Chinese state's proactive and changing engagement in governing the environment since the 2000s, which can be summarized as 'environmentalization.' They rely on similar key concepts found in political ecology (PE), including attention to power and scale, to examine the politics behind environmental issues. Competing values, goals and priorities existing at different scales within the state, and the tensions between different levels and sectors of the governance system exacerbated by decentralization - have been framed by concepts such as fragmented authoritarianism (Ran 2013) and authoritarian environmentalism (Eaton and Kostka 2014). These emphasize the hierarchical, structural and authoritarian nature of state power in China. Recent studies see the state more as an actor than as a system, and show how local politics operates, somewhat separately from central directives (Lo 2015). The increase of liberal practices is associated with the state's promotion of a technocratic and market-based approach for governing the environment, in rhythm with the global progress of neoliberalism. Moreover, currently articulated under the umbrella of "ecological modernization", there is a tendency among academics to accept the Chinese state's approach to managing the environment as a positive shift towards environmental sustainability, without accounting for the risks that result when environmental issues are rendered technical and therefore manageable (Mol and Carter 2006). 
This study argues that PE can make significant contributions to the deeper theorization and analysis of China's environmentalization and its politics. Drawing on theoretical advancement in PE, this study aims to explore how power, scaled politics, and the neoliberal approach - backed by technocratic and market-based measures - are linked in the environmentalization of China. Specifically I will investigate a case of ecological resettlement (called Shengtai Yimin in Chinese and translated as 'ecological resettlement'), where the Chinese state has responded to a combination of new and old problems including sandstorms, desertification and rangeland degradation by resettling pastoralists.

A central task set up in PE has been to understand "where power lies and how it is used" (Blaikie 1985: 6). Geographical scale is central to PE analysis, as geographers have argued (Zimmerer and Bassett 2003). They draw attention to power asymmetries within and between scales, and the scalar practices of social actors (Neumann 2015). However, what political ecologists mean by power and scale has significantly changed over time (Svarstad, Benjaminsen and Overå 2018). The next section will first synthesize the changing conceptualization of power and scale in PE over three phases, especially in relation to desertification, pastoral communities, and in China. Then I introduce the analytics of governmentality and its scalar dimensions: technologies of government, multiple forms of environmentality, and technologies of resistance.

\section{The evolution of ideas of power and scale in PE}

I synthesize the conceptual change of power in PE into three phases. In the first phase, power was conceived as being top-down, structural, repressive and material, present in conflicts over access to resources (e.g. Blaikie and Brookfield 1987; Peluso 1992). State power was perceived to be totalitarian, overarching, and all-seeing. Resistance through material and symbolic actions were also noted (Moore 1993; Peluso 1992). Scott's everyday politics of resistance greatly informed early PE studies on how to look into the informal and subtle politics involved when constraints existed to prevent open, formal and collective action (1985). At this time, the analytical model of a "chain of explanation" employed "a nested set of scales" (Blaikie and Brookfield 1987: 68) to trace the causes of environmental degradation upwards or downwards, while suggesting structureagency/state-society binaries.

In the second phase, although power was still conceived as being repressive and material, its constructive and immaterial dimensions were also analyzed. The analytical focus became deconstructing and questioning power relations and knowledge behind the meta-narratives and scientific assumptions that justify certain actions (Bryant 1998; Forsyth 2004). Scale was used methodologically to distinguish and contrast mismatches between processes or conflicts of interest among actors at different scales. Challenging desertification and land degradation narratives constituted a major theme. Swift (1996) showed how the concept of desertification rested on questionable uses of data and a conflation of separate processes of change, and how it was enlisted by different political and bureaucratic constituencies. Recent research has questioned the undefined and unquantifiable nature of the desertification concept on a global or regional scale (Prince 2016). The Sahelian desertification narrative, used to frame events which never occurred but were widely publicized, has been challenged effectively (Andersson et al. 2011). Moreover, non-equilibrium 'new range ecology' argued the ecology of drylands with high rainfall variability is determined by climatic instead of biotic factors (Behnke and Scoones 1993). This challenged longstanding ideas about ecological equilibrium, carrying capacity and climax vegetation, finding that rangeland degradation and desertification are not caused by overgrazing but are part of a natural process of vegetation decline and growth in response to rainfall. Rangeland management policies which are embedded in an equilibrium model are thus problematic. The disconnection between policy formulation and environmental research on dryland issues has recently been summarized and reemphasized (Behnke and Mortimore 2016).

A group of studies demonstrated specifically the "illegibility of desertification discourses at the local scale" (Adger et al. 2001). The portrait of local pastoralists as victims/losers and agents of desertification, often by journalists and donor agencies, strengthened the position of powerful non-local actors such as colonial and national governments, development agencies and scientists (Swift 1996). Neo-Malthusian and populist 
discourses simplified the local human-environment relationship and swept away the agency of pastoralists, which in turn fed into the technocratic worldview and a managerial discourse of solving the desertification problem (Adger et al. 2001). Despite the call for seeing local dynamics within national or global structures (Sullivan 2000), the idea of desertification is still entrenched at the global scale since it has been institutionalized and "has become a political tool of global importance" (Behnke and Mortimore 2016: 2). The uses and practices of desertification in China repeat many shortcomings of earlier works done in Africa (Jiang 2016). It was also from this phase that a heavy debate over scale took place within PE and in geography (Marston et al. 2005; Moore 2008; Swyngedouw 2004). Among PE scholars nowadays, scale is commonly seen as being socially constructed, relational, contingent and contested (Neumann 2015).

In the third phase when PE research has been greatly inspired by Michel Foucault's idea of governmentality, power is conceived as being capillary and productive, while environmental governance is considered as a complex task of governing a population. Foucault reworked the concept of "government" to distinguish a new form of power from two older forms, sovereignty and discipline, by which he refers to any more or less calculated and rational activity "employing tactics rather than laws, and even of using laws themselves as tactics - to arrange things in such a way, that through a certain number of means, such and such ends may be achieved" (Foucault 1991: 95). In his later work, however, Foucault used four 'governmentalities' to replace the three forms of power: sovereign governmentality, disciplinary governmentality, neoliberal governmentality and truth governmentality, which operate according to different principles but "overlap, lean on each other, challenge each other, and struggle with each other" (Foucault 2008: 313).

Applying the governmentality ideas to analyzing human-nature relations, Luke used the terms "environmentality" and "green governmentality" to refer to the disciplinary articulations of sustainable development which centre on establishing and enforcing "the right disposition of things" between humans and nature (Luke 1999). Later Agrawal used "environmentality" in a broader sense to refer to "the knowledge, politics, institutions and subjectivities that come to be linked together with the emergence of the environment as a domain that requires regulation and protection" (Agrawal 2005: 226). As the environment is considered as a site of power, two matters have been at the core of analysis in PE scholarship: "environmental subject formation" - "how people come to internalize the mandates of the state and the interests of capitalism within themselves" (Robbins 2012: 75), and "technologies of government" "educating desires and configuring habits, aspirations and beliefs" (Li 2007: 5), - what mechanisms, tactics, instruments and rationalities are used to constitute the subjects and territories as "governable" (Rutherford 2007). So the art of government is not only to structure environmental problems but also to provide interventions and solutions (Lloro-Bidart 2015: 4). Corresponding to Foucault's later ideas (Foucault 2008), Fletcher (2010) distinguished four environmentalities based on conservation practices: sovereign environmentality, disciplinary environmentality, neoliberal environmentality and truth environmentality. According to Fletcher, most PE literature has studied disciplinary environmentality (e.g. Agrawal 2005) but he points out the increasing importance of neoliberal environmentality. The trend towards neoliberalization in natural resource management promotes market-based mechanisms or intends to incentivise sustainable utilization through income generation strategies. Practices of neoliberal environmentality seek to govern via external incentives rather than internalized norms and values, as in disciplinary environmentality (McGregor et al. 2015). This literature has discussed the co-working and contradictions between disciplinary and neoliberal governmentality, either in local practices (Youdelis 2013) or between practices at and between different scales (McGregor et al. 2015). Scalar analysis can help to identify the site of government, to spatialize the socio-structural location of governing and to enrich the analysis of the making of governable spaces (Rutherford 2007). After governmentality, analysis of the state focuses on practices rather than objects, strategies instead of functions and technologies instead of institutions (Lemke 2007). People's agency is examined through the lens of subjectivity. By combining resistance with technologies of the governed, Birkenholtz (2009) created the concept of "technologies of resistance" to explain how countermoves to the state's subject making in resource uses are associated with multiple subjectivities due to caste, class and ecological conditions. 
In contrast to the second phase, power associated with governmentality and environmentality has not been used as much to study pastoral issues. Morton (2010) argues that concepts such as the technology of rules, and the interaction of discourse and power, may help to understand pastoral development in Africa. Several studies in China analyze grassland science and policy as tools of state control over territory and people, drawing on the idea of green governmentality to different degrees. The difference between them is that some focused on the technologies of government and interpreted these as the way in which authority is claimed (Kolås 2014; Yeh 2005) and others considered how people are turned into visible subjects for justifying certain forms of governance (Yeh 2009) or how the subjects' imaginations of themselves are limited in certain ways (Williams 2002). The multiple forms of environmentality (Fletcher 2010) have not been distinguished in this literature, but other work drawing on Foucault's governmentality, to study social issues, socialist governmentality and authoritarian governmentality are identified in China and used to highlight the more direct and coercive elements in governmental rationalities in addition to (neo)liberal forms (Dean 2010; Jeffreys and Sigley 2009).

\section{The research context and a multi-scalar methodology}

\section{Research context}

This study focuses on exploring ecological resettlement subordinated to one large-scale national environmental program, the Beijing-Tianjin Sandstorm Source Control Program (hereafter, Program), in a pastoral area of Inner Mongolia Autonomous Region (Inner Mongolia), China. This resettlement scheme aimed to reduce the occurrence of sandstorms in North China, especially those affecting the national capital, Beijing. A win-win scenario was established in political and popular discourses through restoration of degraded rangelands where pastoralists once lived, combined with improvements in their income and living standards in their new locations.

Rangeland degradation is an old problem in the region. Politicians, policy documents, and some research has identified how the large-scale migration of Han peasants into previous pastoral areas at the beginning of the last century led to higher population levels and the conversion of rangeland to farmland, resulted in rangeland degradation. There was also open access to rangelands since the 1970s (Humphery and Sneath 1996; Sheehy 1992). A "tragedy of the commons" was identified and the policy response since the 1980 s was privatizing land, facilitated by measures including stocking rate control and fencing (Banks 2003; Ho 2001; Zukosky 2008). Land privatization took the form of contracting user rights to individual households and continuous institutionalization of such rights through certification. Boundaries had to be clarified.

The case study area, Xilitu Sumu (the township-level administration), located in the Xilingol League (the county level) of Inner Mongolia (province), is a typical desert steppe where the climate is temperate continental, and characterised by low and highly variable precipitation, intense evaporation and strong winds. About 1,500 people or 400 households, mostly Mongolian pastoralists, lived in this extensive area (about 4,000 $\mathrm{km}^{2}$ ) before the resettlement. Their livelihoods relied on herding livestock (Figure 1). Sedentarization and land reform have constituted two key drivers in China's pastoral communities since the 1960s. Before the implementation of resettlement projects, it was uncommon to find households migrating to cities or towns, or quitting their pastoral lifestyle. But today in Xilitu Sumu, most of the pastoral families are sedentary and live in brick-built houses on their rangeland parcels. They hold user rights to the lands until 2026 under the current contract arranged through the Chinese "Household Responsibility System" (HRS). A household with four people holds a large parcel of 15,000 mu (1,000 hectares) on average. The houses, livestock sheds and modern infrastructure are usually constructed on each households' winter pastures, but most wells remain in collective use. Wide access to electricity from the grid came after 2010, but most settlements still lack piped water. Pastoral mobility varies greatly across individual households, but is increasingly restricted to within the boundary of household rangeland parcels. Most herding is managed by individual households, but collaboration between neighbors and kin still exists. 


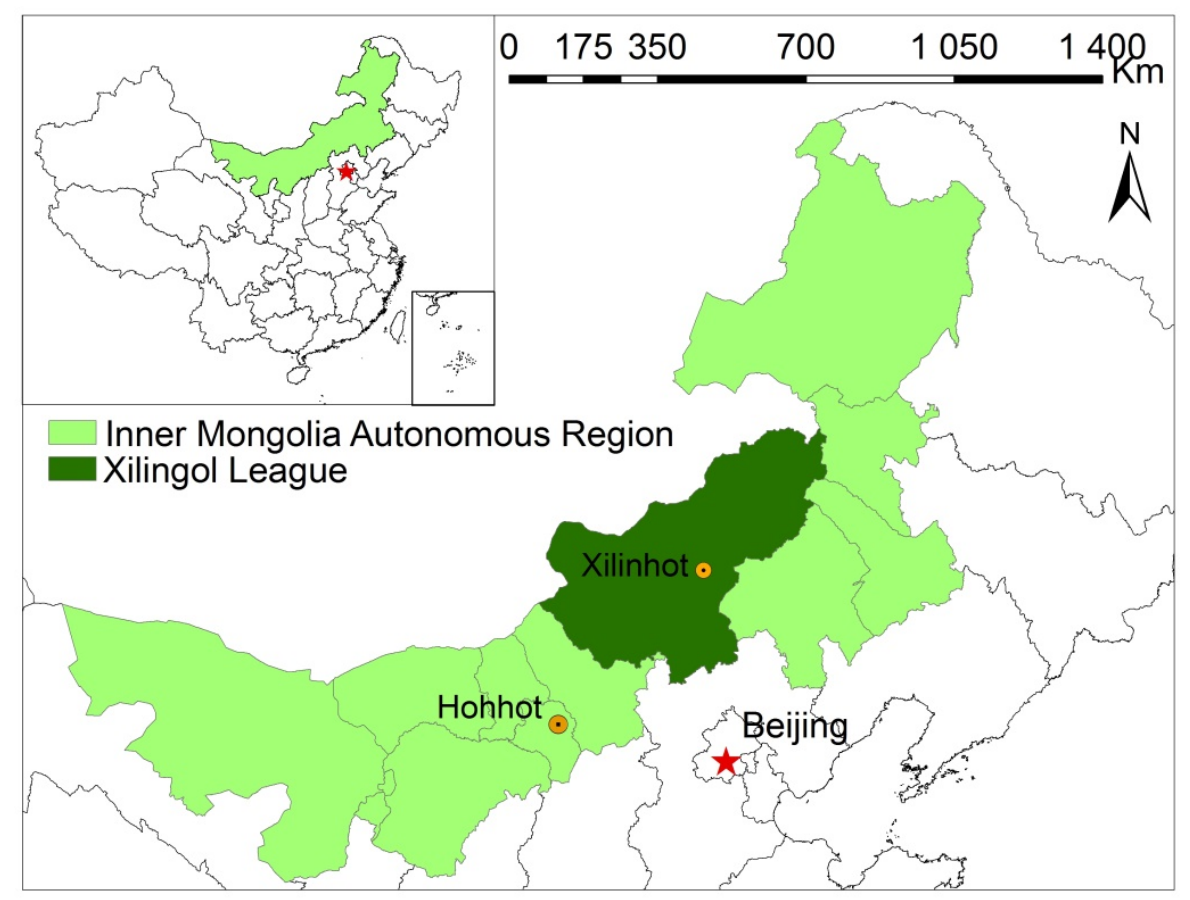

Figure 1. The location of the study area - Xilitu Sumu in Xilingol League in Inner Mongolia, China.

\section{Multi-scalar methodology}

The issue of ecological resettlement came to my attention as I travelled across pastoral areas in Inner Mongolia in 2005, seeing the local specific material existence of resettlement villages. Resettlement, as a new solution to a classical problem - land degradation - was driving unprecedented and dramatic changes in local pastoral communities. After interviewing resettled pastoralists in several identically-structured resettlement villages, I became eager to look into the wider motivations, objectives and planning and finance behind the production of such villages. This required me to collect information from official documents, media reports and prior research. These materials were produced by actors from different places, often far from resettlement sites, and with varied interests and priorities. The surprisingly complex involvement of the environmental, economic and social authorities; the scattered information identified in policy documents; the increasingly science-based ways of talking about environmental problems and solutions made me realize that ecological resettlement is an entry point for looking into a bigger ongoing transformation - the environmentalization of China. In addition, constant media reports were calling for active intervention by the state' to control desertification.

Deeper exploration of the local processes and effects occurred during several periods of fieldwork between 2008 and 2011, with six months in total spent in Xilitu Sumu. Two ecological resettlement projects were carried out in 2001 and 2006 to move the pastoralists to a newly-built settlement, Village S and City Q. ${ }^{2}$ The resettlement destinations are relatively close to Xilitu Sumu. Besides participant observation, interviews were conducted with 70 households composed of both migrants and non-migrants living in the pastoral villages, Village S and City Q. Some 37 of the interviewed households participated in at least one of the projects. Households instead of individuals were chosen as the main unit of research because households constitute the basic units in policy interventions as well as in livelihood organisation. Most of the interviews were conducted in Mandarin, and in Mongolian with the assistance of a translator. One common questionnaire and two separate

\footnotetext{
${ }^{2}$ All names of places and people are anonymised to protect the interviewees.
} 
sets of open-ended questions were used for interviewing participant and non-participant households. The openended questions were designed to examine household migration motivations; strategies and experiences in ecological resettlement; perceptions of environmental changes and the role of the environment in migration decision-making on ecological resettlement; and herding practices before and after resettlement.

Processing and interpretation of fieldwork data was compared with data from written documents. The whole analysis and writing process involved making sense of the scale order, relating processes between scales, and reconstructing a scaled research narrative.

\section{Disentangling multiple forms of power at/across scales in ecological resettlement}

\section{Linking dust in the capital to herding in the periphery}

The story of the sandstorms began with some very visible environmental phenomena. Several consecutive sandstorms swept Beijing between 2000 and 2002, and their impacts were also reported across the wider East Asia region (Chen and Tang 2005; Kar and Takeuchi 2004) and even in the United States (Royston 2001). Policymakers knew the public were aware of storm severity (e.g. Jinghua Times 2005), and official and popular discourses constructed a security threat: if no immediate action was taken, the desert was going to cover Beijing and eastern China, and the health of residents in East Asia and even the United States would be negatively affected. Different estimates and figures that circulated in media reports added to official discourses and sharpened the ecological threat (e.g. Southern Weekly 2001). It was easy for the state to obtain public support for its sandstorm control measures. Together with several other natural hazards taking place over the years, sandstorms were implicated in a general ecological crisis in western China where soil erosion, desertification, deforestation, water scarcity and land degradation were already well known. The occurrence of sandstorms was ascribed to the usual causes - desertification and land degradation. A simple version of the sandstorm crisis related that degraded rangelands were mainly due to overgrazing, created large areas of barren land, whipped up by winds from north to south that transported dust over long distances. The situation would be worse in years of drought. According to the national policymakers, dust and sand in the Beijing area came from the northwest and northern directions, along three main routes. Xilitu Sumu is located on one of these, and it was identified as one of the key source areas for dust, and thus subjected to monitoring and action (City Q Development and Reform Commission 2010).

Two dimensions were significant in giving new life to an old environmental discourse. First of all, the visibility of the sandstorms subjectified certain areas (the source of dust) and certain people (associated with overgrazing). Rendering them visible helped to gain popular legitimacy for strong action. While biophysical processes and the causes of dust storms appear as clear facts in media reports and government documents, dryland science is equivocal. It was after the intensive occurrence of sandstorms that natural scientists started to examine their causation, and their temporal and spatial patterns (e.g. Lv et al. 2004; Ye et al. 2000). While some identified a general increase in sandstorms over the second half of the last century, others found the opposite. Sandstorm formation is still debated, although land cover and metrology are known to be important.

The Chinese state believes controlling sandstorms means controlling sources of sand. However, debates about whether and where desertification/degradation occurs, and the extent and causes of storms, still continue (a short summary is in Zhang 2015: 109). As Williams (2002) said, the Chinese knowledge of land degradation is so objectively constructed that it is seldom problematized. A small number of studies challenge the entrenched belief in anthropogenic desertification and rangeland degradation with empirical evidence of environmental causation, and complexity and uncertainty, but this literature (Harris 2010; Li and Zhang 2009) has had little impact on policymakers.

Interviews with pastoralists in Xilitu sumu also show that they did not accept degradation of their rangelands as the cause of sandstorms. Rather, they observed industrial development, for example mining, as a potential contributor. They also said the shift from collective land rights and mobility towards private ownership and immobile herds was an actual contributor to overgrazing, rather than diminishing it. By applying a stocking rate, removing humans and enclosing rangelands, they argued, rangelands quality would fall. They defined rangelands as naturally dynamic and changeable. Pastoralists have more to gain than anybody from protecting 
the rangelands from erosion, they argued, since they nourish their livestock and support their way of life. They populist accounts of overgrazing. They emphasized the importance of livestock-vegetation interaction for rangeland health, as well as the dynamics of land conditions and most importantly, rainfall.

Secondly, the events and scenarios of sandstorms are used to reconfigure the relations between regions and peoples. Desertification and land degradation are scaled up to affect the entire country and its health, economy and environment (Liu and Diamond 2005; Shen 2004). How pastoralists use land became directly linked to the air quality in Beijing. The objective of the Program was stated in its Plan as "to improve the ecological environment in the capital city and upgrade the international status of Beijing for a green Olympics and secured harmonious economic and social development in the region" (State Forestry Administration 2014). Inner Mongolia was redefined as "an ecological security shelter" linked to national interests, an ecosystem service provider to the capital area (State Council of China 2011). This new positioning reconfigured two previous layers of core-periphery asymmetrical relations. One was between the developed eastern region and the less developed western region as a consequence of an intentional economic policy prioritizing the development of eastern China in the 1980s (Fan 1996). Another was between the barbarian frontier and the civilized agricultural society where the Great Wall used to be a symbolic and ideological barrier (Williams 2002).

\section{"Constructing the ecological security shelter" through "ecological construction"}

The central government's positioning of Inner Mongolia as an "ecological security shelter" had discursive and material effects in the sand source areas like Xilitu Sumu. A group of discourses emphasized a reconstruction approach for the 'degraded' but 'restorable' rangeland. "Ecological construction" (Shengtai Jianshe in Chinese) is a central notion in official discourses. While the term was linked to socialist ideology, meaning to build something new from nothing, its current use is more about fixing and restoring something destroyed. Nevertheless, one may still observe a similarity in previous and current practices - namely, a topdown and large-scale restoration approach. What is quite new is that the term "ecology" has totally occupied the language of environmental governance, in an effort to support its rational and scientific base.

Despite grand perceptions and discourses remaining dominant in political texts, since the 2000s the state has also been developing legal and institutional improvements, alongside ecological knowledge and technical interventions. The former was recognized by political scientists as a positive sign of improved environmental governance in China (Mol and Carter 2006), but the latter is less studied. Technical means are a condition of governing; they are the means for authority to achieve its ends, and they often impose limits on what it is possible to do (Dean 2010: 42). My study identified three trends in 'ecological knowledge and technical interventions.' First of all, monitoring and warning systems were established and developed to collect more data regarding sandstorms, desertification and rangeland degradation. Secondly there was a standardization measurement and the presentation of perceived desertification and grassland degradation. This appears in the Report on the Status Quo of Desertification and Sandification in China, and the National Grassland Monitoring Report. The third trend is the extensive use of statistics in official discourses. They are used to address the severity of conditions, to demonstrate improvements, and to project scenarios. Knowledge-based discourses constitute a new form of power to reach out and transform the population's perception of the issue. These discourses are also powerful in abstracting reality and decontextualizing the localities.

A knowledge-based approach to ecological construction is driven by the state's ambition to keep a "scientific outlook on development" (Kexue Fazhan Guan in Chinese) which emphasizes "scientific planning" (State Council of China 2005). The change of the Chinese term from Jihua to Guihua connotes a more managerial and supervisory role in planning by the government; and it seems to be an important sign of a wider shift in governance, from detailed state planning to more general supervision. However, technical means of planning for operationalizing ecological knowledge face challenges from multi-scaled governance. Inconsistency and even contradictions are common and these are identified in relation to ecological resettlement. "Zoning" ("Quhua" in Chinese) represents a key technique in environmental programs to divide territories, assign new values and further direct different policies towards defined territories. Old technocratic fixes, together with new ones, are organized and allocated to ecological zones. Three zoning plans with maps were 
made by different authorities at the national and prefectural level. ${ }^{3}$ Their classification principles differ, though all consider ecosystem and economic activity features. There is also no explanation of the relations between the three zoning plans, even between the zoning defined in the Program and in the Strategy, despite the latter being a response to the Program.

Although all the zoning plans included ecological resettlement as one of the technocratic fixes, they associated it with zoning in different ways. Xilitu Sumu is classified as a 'Wind Protection' and 'Sand Fixation' Zone in the Zoning of Inner Mongolia, where ecological resettlement is not listed as a technical fix. The application of ecological resettlement is not specified for each zone in the Program. Ecological resettlement is specified in the 'Enclosure and Grazing Prohibition Zone' and 'Sand Land Control Zone' in the Xilingol's Strategy, but resettlement projects can actually be found in all the zones. Moreover, although there is a single national policy document on ecological resettlement, this was defined as a restrictive measure to target "people living in ecologically significant areas, ecologically fragile areas and areas losing basic subsistence conditions" (State Council of China 2002). Nevertheless, the national zoning of ecologically significant and fragile areas came much later in 2008. In practice, many ecological resettlement projects were already initiated before that, as mentioned above. Ultimately, individual zoning may have its own clear rationale but it is unclear how they coordinate with each other. This creates contradictions and tensions in practice, since the zonations suggest different approaches to governing the same space.

\section{Tactics and mechanisms (dis)enabling the multi-scalar practices of ecological resettlement}

The implementation of environmental programs is dependent on multi-scalar coordination within the state, but this is not a top-down and linear process. There is no specific or exclusive policy on ecological resettlement at the national level, but it is indicated as a facilitating measure in various documents related to environment and development. The central government is now more like a planner setting general land use strategies and principles, strengthening knowledge and technical tools for intervention. Nevertheless, direct intervention by political leaders can also result in rapid actions reaching the local level. The rapid launch of the Program was enabled by the ex-Prime Minister's personal visit to several identified dust source fields right after the occurrence of the spring sandstorms in 2000 (China's Green Times 2006).

Lower levels of government do not provide any generic policy to guide ecological resettlement either. Instead, the rules are individually specified in each project case. Regarding ecological resettlement projects in Xilitu Sumu, the Inner Mongolia provincial government was responsible for strategic planning, distributing tasks and allocating funding. The prefectural level of Xilingol League government was responsible for more specific strategic plans and for proposing implementation plans to the provincial government for approval. The county level of government was responsible for detailed planning and implementation of specific projects. Lower levels of government are not just bound by orders to enforce the central government's policy. It is quite common for them to distort, ignore, or even challenge central government initiatives for the sake of local interests and in the absence of proper incentives (Eaton and Kostka 2014; Ran 2013).

In my case study, two mechanisms are used by the central government to discipline the lower levels of government to ensure their compliance. The first mechanism is politicization of staff promotions. Lower level officials' promotions are based on the upper level's evaluation of their political achievements, of which the implementation of ecological resettlement is one. However, official documents from the county and township level governments clearly indicate that the ecological resettlement projects in Xilitu Sumu are political tasks. Two figures are constantly highlighted in almost all the documents to suggest the criteria for achievements the number of resettled households and the size of enclosed rangelands.

The second mechanism is financial support. Large financial budgets appear in official documents, media reports and research to highlight the central government's commitment to solving environmental problems. Financial support to activities in environmental programs is distributed in the form of projects through direct support under the Program, and also from the Western Development Strategy (Xibu Da Kaifa Zhanlue in

\footnotetext{
${ }^{3}$ Zoning in the Program, 'Ecological Function Zoning of Inner Mongolia', and Zoning in Xilingol League's 'Ecological Strategy.'
} 
Chinese, called 'Strategy onwards') (State Council of China 2000). The Strategy intended to shift the priority of development to western China from 2001, and its environmental programs were framed by one of the key Strategy tasks. The ecological resettlement projects in Xilitu Sumu were also financed by a budget for poverty alleviation. Financial support created competition between regions to become part of the Strategy and Program. The Inner Mongolia provincial government actively adapted to the government's position by creating an ecological security frontier, and worked hard with the central authorities to become part of the Strategy so as to receive development support. The county-level government administering Xilitu Sumu claimed that it was through competing with other counties that Xilitu Sumu was finally chosen for implementing resettlement projects. Lower levels of government, needing to raise funds from the centre, also suffered from the appropriation of their fiscal rights in the mid 1990s, and the removal of all agricultural taxes and fees in 2005. Increasing reliance on higher levels of government meant local people suffered, as competition for central funds became a priority.

\section{Making and resisting the subject in local ecological resettlement projects}

The two projects implemented in Xilitu Sumu were associated with very different development models. The first aimed to establish intensive agriculture by organizing and subsidizing pastoralists to produce milk in Village S. Generous support was given, including monthly compensation payments, free housing, subsidies for buying dairy cows, free fodder, skill training, and so-on. At its height, 200 households lived in Village S but more than 80 per cent of the resettled households moved back to their pastoral settlements within two years. The problem was an oversupply of milk due to the extensive application of this model across Inner Mongolia, resulting in a drop in price, high transaction costs for small-scale producers, and a lack of skill in raising dairy cows and cultivating forage. Upon receiving new funding, the local government organised the second project to resettle pastoralists to City Q. By this time the prefectural government had moved towards supporting urbanization, as had central government.

In City Q, a rapidly growing small city with a majority of migrants mainly from Inner Mongolia but also other from parts of China, a neighborhood I call ' $F$ ' was built to accommodate the resettled households, with modern apartments. In addition, professional training and entrepreneurship funding was offered aiming to get pastoralists employed in the industrial and service sectors. Many of the 180 resettled households had family members staying in city $\mathrm{Q}$ but they soon rented out their apartments in neighbourhood $\mathrm{F}$ and moved to cheaper single-storey houses closer to the city center. This maximised rental income and made finding jobs easier, although these ended up being largely in the informal sector. Compensation was the main source of income for most resettled households. A common pattern was that female family members stayed in the city to accompany children attending school, while male family members were more mobile, periodically returning to the pastoral villages to work for families that did not participate in the project or to restart herding of livestock on rented pastures.

Contracts are at the center of the local implementation of ecological resettlement projects. In Xilitu Sumu, every participant household signed an agreement with the township level government to accept a five-year grazing ban on using its rangeland, and in return receiving economic compensation and social support in the town. Under the "voluntary" participation principle, more complex strategies evolved on both sides. In both projects, the local government sought to use two types of strategies to move the pastoralists: a carrot-and-stick approach, and a strategy of creating modern subjects. The carrot strategy focused on creating economic and social incentives to "pull" people to the new destinations while the stick strategy threatened to control pastoral production if they stayed. The other strategy sought to transform them into modern farmers and then into modern urban citizens, with apartments, disposable income, jobs and modern facilities.

Pastoralists had very different motivations and strategies. In the first project, the majority claimed they were motivated by the development dream projected by the local government. Dairying made them believe in a better future. Snow, drought and sandstorms in 2000 assisted recruitment due to a loss of livestock, poor rangeland conditions and minor pessimism. In the second project, few resettled families became modern urban citizens. They variously rejected the project, negotiated to get a better deal, or accommodated and manipulated it (Zhang 2012). The attempts to make the best choice based on their perceptions of opportunities, benefits and 
costs at origin/destination were linked to a fundamental concern about household livelihoods, but not primarily with environmental concerns. The varied responses and discourses are illustration of the technologies of resistance because they are associated with differences in social, economic and political capital.

The pastoral households can be classified into four types, or a "cast of actors" (Adger et al. 2001), to explain the different associations: Warrior, Watcher, Follower and Explorer. Warriors were most resistant to the project because they were managing herds well, and were confident they could make better lives in the pastoral villages than elsewhere. This type of household was mostly headed by middle-aged couples with children at school. Watchers were less resistant to the project but they chose to stay in the pastoral villages because of their dissatisfaction with the benefits on offer. However, they were open to participation in future resettlement if satisfactory benefits were offered. Watcher households were often headed by older people without herds, or dependent children. Participating in the project was considered to be the best choice from the limited options available for Follower families, who were often poor and had few livestock and herders. The compensation offered was critical for sustaining their livelihoods. Explorers were most willing to participate in the project and they were positive about adapting to urban life, even being prepared to move permanently to the city. They often had young laborers who had positive experiences of urban life, or they had enough social and political capital to benefit from the scheme while also continuing herding at home using hired labor.

At the local level, the market economy and neoliberalism has reconfigured the ways in which the state and pastoralists interact. Interestingly, many interviewees commented on the differences between what they learned about the environmental ambitions of the central government, the different policy and practices in other places, and what they experienced. The notion of "a good central government and a bad local government" was often used to express the appreciation of the central government's general intention of protecting rangeland and criticism of the local government's destruction of rangeland through inappropriate fencing - and of the continued struggle to secure local government support. Disciplinary environmentality was accepted at a general level, because there was support for the idea that rangeland should be protected and too many animals would affect it. There was, however, disagreement about the claimed extent, causes and solutions of rangeland degradation. Neoliberal environmentality was less accepted in the second project than the first. Many interviewees claimed that for centuries, being a Mongolian pastoralist has been defined by adapting to the environment through deploying their knowledge of, and interconnections with grasslands. They claimed their traditional mobility strategies could adapt to the varied climate, even though herding is becoming more expensive. But once the first project was underway, more than half of the households had migrated with their herds to stay temporarily on their relatives', friends' or rented rangelands elsewhere. A growth in the market for forage actually increased pastoralists' adaptation capacity without relocation. An assertion by the Warriors group was that remaining a real Mongolian is defined by pastoralism, and resisting resettlement or becoming 'modern.' In this way, a form of 'truth environmentality' was used to counteract 'neoliberal governmentality.'

\section{Discussion}

I have shown how multiple forms of power working at/across scales co-produce an environmentalization discourse. Foucault's governmentality ideas help to define a complex power-scale analysis along three lines: technologies of government, multiple forms of environmentality, and technologies of resistance. On the one hand, places are reconfigured and reimagined by the Chinese state as sites in need of intervention (Rutherford 2007). The intensity of sandstorms gave a new life to the old problems of desertification and degradation. The visibility of the sandstorms was a trigger for the state to turn certain areas (the source areas) and certain people (associated with overgrazing) into subjects of governance. The construction of a crisis scenario facilitated by the media set up a threat/security binary, which emphasized a strong spatial relationship: environmental degradation in western China (the periphery) threatening the security of the capital and the east (the core) and harming the welfare of everybody. Public and media support fed into political discourses and actions to prevent the future occurrence of sandstorms. This process of problem construction is similar to what Walsh (2012) found in Tanzania, where actors behind-the-scenes fostered environmental panic about water shortage around the Mtera hydro-power dam which led to the eviction of pastoralists who were accused of overgrazing their herds. Combatting sandstorms assigned Inner Mongolia to the position of "ecological security shelter", an 
ecosystem provider to the capital and eastern area. This reconfigured spatial relations layered on two previous layers of asymmetrical relations: as part of western China, Inner Mongolia is the less developed area; as the region outside the Great Wall, it is the frontier. The intersection of the different layers of relations situates environmental governance in Inner Mongolia as part of the political economy of developing western China.

On the other hand, rationalization of environmental problems, active incorporation of science and ecological knowledge, and systematic adoption of planning and technical tools create "conditions of governing" (Dean 2010: 42). In line with with earlier PE studies problematizing narratives and knowledge, this study also shows that desertification and degradation are unclear concepts that are taken to be clear truths, in order to facilitate the circulation of populist views and to justify political actions (Behnke and Mortimore 2016; Swift 1996). A similar storyline emerged in this case: due to the "ecological crisis" (causes/facts) signed by sandstorms, "ecological construction" is needed (solutions/approaches) in order to achieve "ecological restoration/rehabilitation" (aims). "Ecological construction" was carried out through ecological knowledge construction and by technical interventions. The state, scholars and pastoralists have quite different understandings of rangelands. The construction of the authoritative knowledge system is top-down, scanting appreciation of pastoralist's knowledge and its complexity and uncertainty. This case contributes another example of Adger et al.'s observed pattern of global desertification discourses, in which neo-Malthusian and populist discourses simplify the local human-environment relationship and underrate the agency of farmers and pastoralists, feeding into a technocratic worldview and a managerial discourse that sees the desertification problem as solvable (2001). In this sense, what happens in China repeats the problematic governance approach documented in African drylands (Behnke and Mortimore 2016).

Unlike previous PE studies, knowledge and discourse construction have been linked to a larger perspective of governing the population and territory. Ecological resettlement illustrates the environmentalization of the state, as a form of "governmentalization of the state" (Dean 2010: 267) - drawing attention to new practices, strategies and technologies enabling the operation of state power. Unlike in African contexts where there are several powerful actors other than the state such as development donors and NGOs that shape the issue of degradation, it is mainly the Chinese state which dominates environmental governance.

This analysis shows that controlling sandstorms and land degradation is a process of making and contesting an environmental state in China. The powerful role of the state is enabled by its rapid growing economy, reducing dependence on international development aid and limited space for NGOs and other actors. The environmental state is not taken as one actor, but as several involved in regulating land and people. Unlike the processes in many resource-rich and capital-poor developing countries where an environmental state is constructed by the strong drivers of globalization and hegemonic transnational practices (Goldman 2001), environmentalization in China is a proactive shift by the state. Policy formulation in China actively incorporates science, unlike some of the examples in Behnke and Mortimore's account of desertification policy (2016). Standardization and institutionalization of desertification and rangeland degradation discourses have been guided by the state's pursuit of a scientific development outlook. Fundamentally though, governing the environment is used to achieve 'development.'

By distinguishing multiple forms of environmentality, especially working at/across scales, the analysis has been able to achieve deeper understanding of strategies and practices, with the tensions and conflicts that they create. The shift of the central government to supervisory governance, ceding some authority to local government, has been enabled by planning, mapping and statistics. However, environmental governance is constantly challenged by inconsistencies and even contradictions between different authorities at different levels, when applying technical means and operationalizing ecological knowledge. Relying on two main mechanisms, political promotion and financial transfers to incentivize the lower levels of government, the central state has adopted more neoliberal forms of power to roll out its environmental will. Nevertheless, 'sovereign environmentality' is still significant, where subjects are compelled to obey sovereign will by direct threat of punishment (Fletcher 2010). Top political decisions can still effectively lead to immediate actions at the ground level. Meanwhile, political performance evaluation and financial transfer seek to scaffold the implementation of environmental projects. The authoritarian side of the political structure also facilitates formality and a kind of unified appearance of the articulation of problems and solutions with certain territories and peoples. Zukosky (2008) called this the semblance of modern rationality and order. 
While the central government attempted to produce environmental subjects who are self-monitoring and supportive of restricting their own activities through state intervention (Agrawal 2005), the local government in contrast made few attempts to produce environmental subjects, instead promoting the creation of modern economic subjects. Environmental subject-making, "educating desires and configuring habits, aspirations and beliefs" (Li 2007: 5), is more evidently practised by the central state as a part of gaining legitimacy through environmental intervention. The local state educated pastoralists to become modern (urban) subjects rather than environmental subjects. This worked together with the offer of social and economic support. Through "manipulating market-based incentive structures" the local government motivated some pastoralists to move as exhibiting the "appropriate behaviours" (Fletcher 2010).

Power and resistance are co-produced from the governmentality perspective (Rutherford 2007). Technologies of resistance (Birkenholtz 2009) emerge in response to central and local government. The subject of the general population has been successfully transformed by the central government to support the state's active interventions in the environment through carrying out environmental projects. While local pastoralists accepted the central government's general call for conserving rangelands, they were resistant to the specific rationalities accounting for the extent, causes and solutions to rangeland degradation. Moreover, pastoral families responded differently to modern subject-making at different moments in time. Even though pastoralists who participated in the projects did not consider the move would help to solve sandstorms, some were still willing to approach modern development (the Explorers). Pragmatic considerations of livelihoods bound to the wider context of the state's rapid move towards modernization, urbanization and market economy constitute strong forces transforming pastoralists into modern subjects. Thus, neoliberal incentives work as means for the local government to engage the people (especially Followers) and they allow some people to exercise power through negotiation. Tensions and resistance was often connected to the disagreement local government and pastoralists over the terms of resettlement. So pastoralists who did not participate in the projects at all were not necessarily against modern subject-making, but they were unsatisfied with the incentives offered (the Watchers). There were also those who were openly against modern subject-making, making claims about the importance of their pastoral identity and lifestyle (the Warriors). This illustrates how truth environmentality was used to counteract neoliberal governmentality. Even though pastoralists could choose to stay, they were threatened by the local government with more restrictions on their land use, suggesting the continued significance of sovereign environmentalities.

\section{Conclusion}

In sum, the simultaneous deployment of disciplinary and neoliberal environmentality places conservation and development interests in opposition (see also Lloro-Bidart 2015 and Youdelis 2013). There are contradictions associated with multi-scalar practices. Sovereign environmentality, under-investigated in existing studies, is important for understanding state-led environmental programs.

The study demonstrates how political ecology can contribute to a deeper theorization and analysis of environmentalization in China. The multiple governmentality perspective highlights different forms of power that are embodied in the range of strategies used by the state to 'solve' the sandstorm problem. The study has drawn on analytics from three components of this multiple governmentality perspective - technologies of government, multiple forms of environmentality, and technologies of resistance, to disentangle scalar processes. Scale, much more than 'level', demonstrates the unfolding and the tensions of the different dimensions of the environmental state.

Despite showing great similarities with early PE studies on desertification and pastoralists in terms of knowledge and discourse construction, a governmentality analytic highlights how struggles over knowledge and discourses emerge in order to govern the local population and their territories. Environmental governance is a component of state-building, in which actors at different scales of the government deploy strategies and tactics to discipline as well as to cultivate self-government, reconfiguring spatial relations. Multiple forms of environmentality exist, and disciplinary and neoliberal environmentality are associated with different scalar practices within the state system, and among the local population. Neoliberal environmentality, however, counteracts the making of environmental subjects. Sovereign environmentality, which is given little attention 
in political ecology, is still used to compel the local government and to obtain obedience from local pastoralists. Resistance to the state's attempts at governance varies across pastoral households based on their subjectivities. Resistance in the resettlement projects is more often against modern subject-making than environmental subject-making.

\section{References}

Adger, W.N., T.A. Benjaminsen, K. Brown, K. and H. Svarstad. 2001. Advancing a political ecology of global environmental discourses. Development and Change 32(4): 681-715.

Agrawal, A. 2005. Environmentality: technologies of government and the making of subjects. Durham, NC: Duke University Press.

Andersson, E., S. Brogaard and L. Olsson. 2011. The political ecology of land degradation. Annual Review of Environment and Resources 36: 295-319.

Banks, T. 2003. Property rights reform in rangeland China: dilemmas on the road to the household ranch. World Development 31(12): 2129-2142.

Behnke, R. and M.J. Mortimore (eds.). 2016. The end of desertification? Disputing environmental change in the drylands. Berlin: Springer.

Behnke, R.H. and I. Scoones. 1993. Rethinking range ecology: implications for rangeland management in Africa. In Behnke, R.H. and I. Scoones (eds.). Range ecology at disequilibrium: new models of natural variability and pastoral adaptation in African savannas. London: Overseas Development Institute. Pp. 1-30.

Birkenholtz, T. 2009. Groundwater governmentality: hegemony and technologies of resistance in Rajasthan's (India) groundwater governance. The Geographical Journal 175(3): 208-220.

Blaikie, P.M. 1985. The political economy of soil erosion in developing countries. London: Longman.

Blaikie, P.M. and H.C. Brookfield. 1987. Land degradation and society. London: Methuen.

Bryant, R.L. 1998. Power, knowledge and political ecology in the third world: a review. Progress in Physical Geography 22(1): 79-94.

Chen, Y. and H. Tang. 2005. Desertification in north China: background, anthropogenic impacts and failures in combating it. Land Degradation and Development 16: 367-376.

China's Green Times. 2006. Serial report on Beijing-Tianjin Sandstorm Source Control Programme I. China's Green Times http://www.forestry.gov.cn/portal/main/s/72/content-361748.html.

City Q Development and Reform Commission. 2010. Ecological construction and ecological resettlement program study report (in Chinese).

Dean, M. 2010. Governmentality: power and rule in modern society. Thousand Oaks, CA: Sage.

Eaton, S. and G. Kostka. 2014. Authoritarian environmentalism undermined? Local leaders' time horizons and environmental policy implementation in China. The China Quarterly 218: 359-380.

Fan, C.C. 1996. Economic opportunities and internal migration: a case study of Guangdong Province, China. The Professional Geographer 48(1): 28-45.

Fletcher, R. 2010. Neoliberal environmentality: towards a poststructuralist political ecology of the conservation debate. Conservation and Society 8(3): 171-181.

Forsyth, T.J. 2004. Critical political ecology: the politics of environmental science. London: Routledge.

Foucault, M. 2008. The birth of biopolitics. New York: Palgrave Macmillan.

Foucault, M. 1991. Governmentality. In Burchell, G., Gordon, C. and Miller, P. (eds.). The Foucault effect: studies in governmentality: with two lectures by and an interview with Michel Foucault. Chicago: University of Chicago Press. Pp. 87-104.

Goldman, M. 2001. Constructing an environmental state: eco-governmentality and other transnational practices of a 'green' World Bank. Social Problems 48(4): 499-523.

Harris, R.B. 2010. Rangeland degradation on the Qinghai-Tibetan plateau: a review of the evidence of its magnitude and causes. Journal of Arid Environments 74(1): 1-12.

Ho, P. 2001. Who owns China's land? Policies, property rights and deliberate institutional ambiguity. The China Quarterly 166: 394-421. 
Humphery, C. and D. Sneath. 1996. Culture and environment in Inner Asia: the pastoral economy and environment. Volume I. Cambridge: White Horse Press.

Jeffreys, E. and G. Sigley. 2009. Governmentality, governance and China. In Jeffreys, E. (ed.). China's governmentalities: governing change, changing government. London: Routledge. Pp. 1-23.

Jiang, H. 2016. Taking down the "Great Green Wall": the science and policy discourse of desertification and its control in China. In Behnke, R. and M.J. Mortimore (eds.). The end of desertification? Disputing environmental change in the drylands. Berlin: Springer. Pp. 513-536.

Jinghua Times. 2005. To prevent sand storm rage in Beijing, five hundred thousand "ecological migrants" need to be moved in Beijing-Tianjin region. Jinghua Times http://politics.people.com.cn/GB/14562/3236786.html.

Kar, A. and K. Takeuchi. 2004. Yellow dust: an overview of research and felt needs. Journal of Arid Environments 59: 167-187.

Kolås, Å. 2014. Degradation discourse and green governmentality in the Xilinguole grasslands of Inner Mongolia. Development and Change 45(2): 308-328.

Lemke, T. 2007. An indigestible meal? Foucault, governmentality and state theory. Distinktion: Journal of Social Theory 8(2): 43-64.

Li, T.M. 2007. The will to improve: governmentality, development, and the practice of politics. Durham, NC: Duke University Press.

$\mathrm{Li}, \mathrm{W}$. and Q. Zhang. 2009. Interpreting the dilemma of rangeland management: understanding rangeland use and management in arid and semi-arid areas. Beijing: Economy and Science Press.

Liu, J.G. and J. Diamond. 2005. China's environment in a globalizing world: how China and the rest of the world affect each other. Nature 435(30): 1179-1186.

Lloro-Bidart, T. 2015. Neoliberal and disciplinary environmentality and 'sustainable seafood' consumption: storying environmentally responsible action. Environmental Education Research 23(8): 1182-1199.

Lo, K. 2015. How authoritarian is the environmental governance of China? Environmental Science and Policy 54: 152-159.

Luke, T.W. 1999. Environmentality as green governmentality. In Darier, E. (ed.) Discourses of the environment. Oxford: Blackwell. Pp. 121-151.

Lv, X.M., H.C. Liu, W.J. Wang and S.H. Wu. 2004. Spatial and temporal distribution characteristics of sand and dust storms around Beijing Region. Geographical Research (地理研究) 23(1): 38-44.

Marston, S.A., J.P. Jones and K. Woodward. 2005. Human geography without scale. Transactions of the Institute of British Geographers 30(4): 416-432.

McGregor, A., E. Challies, P. Howson, R. Astuti, R. Dixon, B. Haalboom, M. Gavin, L. Tacconi and S. Afiff. 2015. Beyond carbon, more than forest? REDD governmentality in Indonesia. Environment and Planning A 47(1): 138-155.

Mol, A.P. and N.T Carter. 2006. China's environmental governance in transition. Environmental Politics 15(2): 149-170.

Moore, A. 2008. Rethinking scale as a geographical category: from analysis to practice. Progress in Human Geography 32(2): 203-225.

Moore, D.S. 1993. Contesting terrain in Zimbabwe's eastern highlands: political ecology, ethnography, and peasant resource struggles. Economic Geography 69(4): 380-401.

Morton, J. 2010. Why should governmentality matter for the study of pastoral development? Nomadic Peoples 14(1): 6-30.

Neumann, R.P. 2015. Political ecology of scale. In Bryant, R.L. (ed.) The international handbook of political ecology. London: Edward Elgar. Pp. 475-486.

Peluso, N.L. 1992. Rich forests, poor people: resource control and resistance in Java. Berkeley: University of California Press.

Prince, S.D. 2016. Where does desertification occur? Mapping dryland degradation at regional to global scales. In Behnke, R. and M.J. Mortimore (eds.). The end of desertification? Disputing environmental change in the drylands. Berlin: Springer. Pp. 225-263. 
Ran, R. 2013. Perverse incentive structure and policy implementation gap in China's local environmental politics. Journal of Environmental Policy and Planning 15(1): 17-39.

Robbins, P. 2012. Political ecology: a critical introduction. Oxford: Blackwell.

Royston, R. 2001. China's dust storms raise fears of impending catastrophe. National Geographic News http://news.nationalgeographic.com/news/2001/06/0601_chinadust.html.

Rutherford, S. 2007. Green governmentality: insights and opportunities in the study of nature's rule. Progress in Human Geography 31(3): 291-307.

Scott, J.C. 1985. Weapons of the weak: everyday forms of peasant resistance. New Heaven: Yale University Press.

Sheehy, D.P. 1992. A perspective on desertification of grazing land ecosystems in north China. Ambio 21(4): 303-307.

Shen, J.F. 2004. Population growth, ecological degradation and construction in the western region of China. Journal of Contemporary China 13(41): 637-661.

Southern Weekly. 2001. Review: whether we can conquer ourselves - the key of controlling sand storm. Southern Weekly http://news.sina.com.cn/c/226369.html.

State Council of China. 2011. Several opinions on further promoting good and quick economic and social development of Inner Mongolia. Guofa 21.

State Council of China. 2005. Decisions regarding implementing scientific outlook to strengthen environmental protection. Guofa 39.

State Council of China. 2002. Several opinions on improving the measures of the returning farmland to forestry policy. Guofa 10.

State Council of China. 2000. Implementation opinions on the several policy measures of Western Development Strategy. Guofa 33.

State Forestry Administration. 2014. Programme Plan of Sandstorm Source Control in Beijing-Tianjin Region. http://english.forestry.gov.cn/index.php/best-practice/desert-ecosystem/187-program-plan.

Sullivan, S. 2000. Getting the science right, or introducing science in the first place? Local 'facts', global discourse - 'desertification' in north-west Namibia. In Stott, P. and S. Sullivan (eds.). Political ecology: science, myths and power. London: Arnold. Pp. 15-45.

Svarstad H., T.A. Benjaminsen and R. Overå. 2018. Power theories in political ecology. Journal of Political Ecology 25: 350-363.

Swift, J. 1996. Desertification: narratives, winners and losers. In Leach, M. and R. Mearns (eds.). The lie of the land: challenging received wisdom on the African environment. Oxford: James Currey. Pp. 73-90.

Swyngedouw, E. 2004. Scaled geographies: nature, place, and the politics of scale. In Sheppard, E.S. and R.B. McMaster (eds.) Scale and geographic inquiry: nature, society, and method. Oxford: Blackwell. Pp. 129-153.

Walsh, M. 2012. The not-so-great Ruaha and hidden histories of an environmental panic in Tanzania. Journal of Eastern African Studies 6(2): 303-335.

Williams, D.M. 2002. Beyond Great Walls: environment, identity, and development on the Chinese grasslands of Inner Mongolia. Stanford: Stanford University Press.

Ye, D.Z., J.F. Chou and J.Y. Liu. 2000. Causes of sand-stormy weather in northern China and control measures. Acta Geographica Sinica (Chinese Edition) 55(5): 513-552.

Yeh, E.T. 2015. Political ecology in and of China. In Bryant, R.L. (ed.). The international handbook of political ecology. London: Edward Elgar. Pp. 619-632.

Yeh, E.T. 2009. Greening western China: a critical view. Geoforum 40(5): 884-894.

Yeh, E.T. 2005. Green governmentality and pastoralism in western China: 'converting pastures to grasslands'. Nomadic Peoples 9(1-2): 9-30.

Youdelis, M. 2013. The competitive (dis) advantages of ecotourism in Northern Thailand. Geoforum 50: 161171.

Zhang, Q. 2015. Pastoralists and the environmental state: a study of ecological resettlement in Inner Mongolia, China. PhD dissertation. Department of Human Geography, Stockholm University. 
Zhang, Q. 2012. The dilemma of conserving rangeland by means of development: exploring ecological resettlement in a pastoral township of Inner Mongolia. Nomadic Peoples 16(1): 88-115.

Zimmerer, K. and T. Bassett. 2003. Approaching political ecology. In Zimmerer, K. and T.J. Bassett (eds.). Political ecology: an integrative approach to geography and environment-development studies. New York: Guilford Press. Pp. 1-25.

Zukosky, M.L. 2008. Reconsidering governmental effects of grassland science and policy in China. Journal of Political Ecology 15: 44-60. 